\title{
Comparative Analysis of Shear Strength Parallel to Fiber of Different Local Bamboo Species in the Philippines
}

\author{
Brian E. Bautista ${ }^{1, *}$, Lessandro E. O. Garciano ${ }^{1}$ and Luis F. Lopez ${ }^{2}$ \\ 1 Department of Civil Engineering, De La Salle University, Manila 0922, Philippines; \\ lessandro.garciano@dlsu.edu.ph \\ 2 Base Bahay Foundation Inc., Makati 1231, Philippines; luis.lopez@base-bahay.com \\ * Correspondence: brian_bautista_a@dlsu.edu.ph
}

Citation: Bautista, B.E.; Garciano, L.E.O.; Lopez, L.F. Comparative Analysis of Shear Strength Parallel to Fiber of Different Local Bamboo Species in the Philippines. Sustainability 2021, 13, 8164. https:// doi.org/10.3390/su13158164

Academic Editors: Edwin B. Zea Escamilla and David Trujillo

Received: 12 June 2021

Accepted: 15 July 2021

Published: 21 July 2021

Publisher's Note: MDPI stays neutral with regard to jurisdictional claims in published maps and institutional affiliations.

Copyright: (c) 2021 by the authors. Licensee MDPI, Basel, Switzerland. This article is an open access article distributed under the terms and conditions of the Creative Commons Attribution (CC BY) license (https:// creativecommons.org/licenses/by/ $4.0 /)$.

\begin{abstract}
There are limited published studies related to the mechanical properties of bamboo species in the Philippines. In this study, the shear strength properties of some economically viable bamboo species in the Philippines were properly characterized based on 220 shear test results. The rationales of selecting this mechanical property are the following: (1) Shear strength, parallel to the fiber, has the highest variability among the mechanical properties; and (2) Shear is one of the governing forces on joint connections, and such connections are the points of failure on bamboo structures when subjected to extreme loading conditions. ISO 22157-1 (2017) test protocol for shear was used for all tests. The results showed that Bambusa blumeana has the highest average shear strength, followed by Gigantochloa apus, Dendrocalamus asper, Bambusa philippinensis, and Bambusa vulgaris. However, comparative analysis, using One-way ANOVA, showed that shear strength values among these bamboo species have significant differences statistically. A linear regression model is also established to estimate the shear strength of bamboo from the physical properties. Characteristic shear strength is also determined using ISO 12122-1 (2014) for future design reference.
\end{abstract}

Keywords: Bambusa blumeana; Gigantochloa apus; Dendrocalamus asper; Bambusa philippinensis; Bambusa vulgaris; bamboo; mechanical properties; ISO 22157-1; ISO 12122-1

\section{Introduction}

Over the years, there is a pervasive drive to shift towards sustainable practices in the construction industry. Such spread in sustainable practices is due to climate change and environmental impacts that construction makes [1]. Bamboo is known in some parts of the world as "green gold" as this fast-growing grass plant has proven to combat several global challenges, which include rural poverty, land degradation, deforestation, urban development, unsustainable resources, and climate change [2,3]. Bamboo forests are also known to be a significant carbon sink in global carbon cycles, especially in China. Since the 1950s, carbon stocks in bamboo forests have risen considerably, from 318.55 to $631.58 \mathrm{Tg} \mathrm{C}[4,5]$. Bamboo is considered as a potential alternative building material to wood [6,7], primarily, and to steel and concrete [8,9]. In a life cycle assessment (LCA) study, which compares the use of some of the common materials in the construction of single and multi-story buildings, such as bamboo poles, brick, hollow block, and engineered bamboo, it was found out that engineered bamboo construction system has the lowest environmental impact while the highest contributor arises from the transport and reinforcing materials [9]. One application of engineered bamboo is the Bamboo Winding Composite Pipe (BWCP), which modernizes the use of bio-based pipes in below-ground water reticulation infrastructure and is viewed as a viable alternative to PVC and concrete pipe, particularly in low to medium pressure water service and sewerage applications [10]. More importantly, these BWCP have a considerable carbon storage capacity over time, with an estimated 0.5 tons of atmospheric $\mathrm{CO}_{2}$ sequestered per ton of pipe manufacturing [10]. For structural applications, laminated bamboo lumber, glue-laminated bamboo, and parallel strand bamboo are the most widely 
used engineered bamboo materials because of their good mechanical qualities, shape standardization capability, minimal variability in material attributes, and sustainability potential [11]. Another study examines the long-term sustainability of glue-laminated bamboo, glue-laminated wood, and concrete hollow blocks, as applied to housing projects. When compared to glue-laminated wood and concrete hollow block, the sustainability assessment reveals that glue-laminated bamboo is the most sustainable choice for housing programs, as it is more capable of reducing $\mathrm{CO}_{2}$ emissions while also potentially avoiding emissions from fossil fuels [12]. In comparison to the other two materials, the potential for employment development with glue-laminated bamboo is also larger [12].

The Philippines is the world's 6th largest exporter of bamboo and other rattan products [13]. In the local setting, one of the primary demands for bamboo for housing purposes arises from the need for new house construction and repair and replacement of existing houses [14]. The demand for bamboo is highest among rural households, which combine bamboo with other low-cost construction materials [14]. The total need for housing units in the Philippines is 6,226,940 [15]. Apart from that backlog, 345,941 units are the average housing unit requirement per year from 2012 to 2030 while the average housing production capacity is currently pegged at 200,000 units per year [15]. Based on these data, there is a yearly backlog of 145,941 units if no social program is created. If the housing production capacity remains the same and that the backlog from 2011 is already met, there are still $3,459,410$ housing units required from 2020 until 2030. The demand for housing, especially in economic and socialized housing market segments, is indeed a problem that must be addressed.

Because of the need for the use of bamboo, especially for the modular housing components in the Philippines, there must be an effort to understand the bamboo species endemic in the Philippines. Information on the physical and mechanical properties of bamboo is essential for evaluating its suitability and utility for numerous end products [16-18]. The testing method to be used in this study is ISO 22157-1, Bamboo-Determination of Physical and Mechanical Properties. This testing method is established "to bring bamboo towards the level of an internationally recognized and accepted building and engineering material" [19]. This testing method is proven invaluable as a basis to ensure that test results between researchers are comparable [20]. Further, repeatability and minimizing inter-laboratory variation to the fullest extent possible is critical so that a description of bamboo materials is as uniform as possible; thereby creating a lingua franca among practitioners [21]. The next step from international standardization is the creation of national bamboo standards specific to bamboo growing countries [22]. The adoption of standards and codes encourages even more innovation [23]. Emerging green construction standards, for example, are spurring the development of new building materials and procedures to help meet the standards' objectives [23]. Indeed, material characterization, especially on a sustainable material such as bamboo, is a step towards contributing to a growing body of research and present areas in which further investigation is needed.

This study intends to focus on the shear strength of bamboo, parallel to fiber, for bamboo species in the Philippines. ISO 12122-1-Determination of Characteristic Values is used to develop a uniform description of the characteristic strength of the bamboo species used in this study. In the local setting, studies about the shear strength of bamboo parallel to fiber have sporadically come. Out of the many bamboo species in the Philippines, only the Bambusa blumeana has gained significant attention. Salzer et al. [19] investigated the mechanical properties of this species and their result on the characteristic shear strength is pegged at $5 \mathrm{MPa}$. In another study by Cantos et al. [24], about the same species, the resulting average shear strength is $8.80 \mathrm{MPa}$. As of writing, there were no other published studies that investigate the shear strength parallel to fiber for other Philippine bamboo species. Thus, this study pushes to investigate this mechanical property for other bamboo species while establishing a minimum required number of samples to achieve results within $\pm 1 \mathrm{MPa}$ interval with a $95 \%$ level of confidence. 
The following are the other reasons why shear strength parallel to the fiber is selected as the mechanical property of study: (1) The shear strength parallel to the fiber has the highest variability [25]. The result of this study will establish a distinct range of values for the prevalent bamboo species thereby addressing such variability. (2) Shear is one of the key stresses that must be considered in structural member design, especially in the following stress states: external forces producing in-plane lateral loads, transverse loads in deep beams, or torsional moments in columns [26]. Compared to normal stresses, these conditions result in high shear stresses. These stress states could be classified as pure shear and represented by a direct shear experimental test [26]. (3) Shear forces are crucial in joint connection design. For example, bolted joints are commonly employed in bamboo structures because they are simple, reliable, and convenient. However, studies show that holes from these bolted connections reduce the shearing strength of bamboo culms [27].

Another important aspect of this research is to determine the correlation of physical properties, such as density, to that of the shear strength parallel to fiber. A rule of thumb was established by Jansen [28] that relates shear strength with density for air-dry bamboo. Based on the rule, the ratio of the ultimate stress in $\frac{\mathrm{N}}{\mathrm{mm}^{2}}$ and the mass per volume in $\frac{\mathrm{kg}}{\mathrm{m}^{3}}$ is equal to 0.021 . This capability to approximate the mechanical properties of bamboo is especially useful in contexts of nurseries and in forests where there is limited access to testing facilities. This study aims to develop the same correlation for Philippine bamboo species. Finally, Analysis of Variance (ANOVA) and Student's $t$-tests are used to compare the results of the study statistically.

A limitation of this study is the method of sampling along the length of the bamboo culm. Various literature suggests that the strength of the node and internode may be influenced by the location where the sample is obtained (i.e., from the top, middle, and bottom). However, due to the limited number of available samples for each species, this was not considered in this study. Nevertheless, an unbiased randomized way of sampling was employed during the sampling.

\section{Materials and Methods}

The shear strength properties of some economically viable bamboo species in the Philippines, e.g., Gigantochloa apus (local name-Apus), Bambusa philippinensis (local nameLaak), Bambusa vulgaris (local name-Lunas), Dendrocalamus asper (local name-Botong), and Bambusa blumeana (local name-Kawayan Tinik) were properly characterized based on 220 shear test results. This is one of the most comprehensive studies about the characterization of the shear strength of bamboo in the Philippines due to the number of species and specimens obtained during the test. A total of 120 specimens were tested for Gigantochloa apus, Bambusa philippinensis, Bambusa vulgaris, and Dendrocalamus asper with 30 specimens for each bamboo species, while 100 specimens were tested for Bambusa blumeana species. The study established the average shear strength and characteristic shear strength of these bamboo species as a future design reference in the local practice. A comparative analysis was also done to determine the hierarchy of these bamboo species in terms of shear strength. The testing method used was ISO 22157-1 (2017) test protocol for shear [29]. Appropriate experimentation requirements and instrumentations were followed based on this testing protocol as discussed in this section. All the tests were conducted at the Base Bahay Innovation Center (BIC) located in Makati, Philippines. A Shimadzu AGS-100 kN Xplus Universal Testing Machine (UTM) was used for load application. A summary of all the testing equipment is shown in Table 1. 
Table 1. Summary of apparatus used with the corresponding brand, material, and equipment description.

\begin{tabular}{|c|c|c|c|}
\hline $\begin{array}{l}\text { Apparatus } \\
\text { Needed }\end{array}$ & Apparatus Used & Brand/Material & Description \\
\hline Test Machine & $\begin{array}{l}\text { Universal } \\
\text { Testing } \\
\text { Machine }\end{array}$ & $\begin{array}{l}\text { Shimadzu AGS-100 } \\
\text { kN Xplus }\end{array}$ & $\begin{array}{l}\text { - Capable of measuring compressive load with a } \\
\text { precision of at least } 1 \% \\
\text { - } \quad \text { Machine capacity of } 100 \mathrm{kN}\end{array}$ \\
\hline $\begin{array}{l}\text { Measuring } \\
\text { Instrument }\end{array}$ & Digital Caliper & No brand & $\begin{array}{l}\text { - Capable of determining the length of the culm } \\
\text { with a precision of } 0.5 \% \text { of the specimen mass }\end{array}$ \\
\hline Balance & Weighing Scale & $\begin{array}{l}\text { No brand, Model } \\
\text { XY2000-2C }\end{array}$ & $\begin{array}{l}\text { - Capable of weighing specimen with a precision } \\
\text { of } 0.5 \%\end{array}$ \\
\hline $\begin{array}{l}\text { Heating } \\
\text { Instrument }\end{array}$ & Oven & Esco Isotherm & $\begin{array}{l}\text { - Capable of drying bamboo to the absolute dry } \\
\text { condition }\end{array}$ \\
\hline Cutting Instrument & Mechanical Saw & Makita LS1221 & $\begin{array}{l}\text { - Capable of cutting specimen with high precision to } \\
\text { ensure both ends are parallel }\end{array}$ \\
\hline Loading Plates & Shear Plates & 2 pcs steel shear plates & $\begin{array}{l}\text { - Capable to support the specimen at its lower end } \\
\text { over two opposing quadrants } \\
\text { - Capable to load the specimen at its upper end over } \\
\text { the other two opposing quadrants }\end{array}$ \\
\hline $\begin{array}{l}\text { Positioning } \\
\text { Instrument }\end{array}$ & Steel Rods & $\begin{array}{l}2 \text { pcs } 10 \text { mm diameter } \\
\text { steel rod }\end{array}$ & Capable to seat the specimen and the shear plates \\
\hline
\end{tabular}

\subsection{Data Collection-Pre-Testing}

A sample test specimen is shown in Figure 1. The bamboo specimen is a round bamboo with a length equal to the lesser value between the diameter and ten times the wall thickness. A total of 8 control points are established for each specimen, 4 each at the top and bottom of the specimen. Individual measurements of length, thickness, and diameter are done using these control points. Measurements are done using a digital vernier caliper with a precision of $0.5 \%$. Proper due diligence is carried out in ensuring that the ends of the samples are completely parallel to each other such that the samples will be at a $90^{\circ}$ angle with the shear plates. Defects on the samples, such as holes or cracks, are also checked. Defective and unparallel samples are immediately rejected.
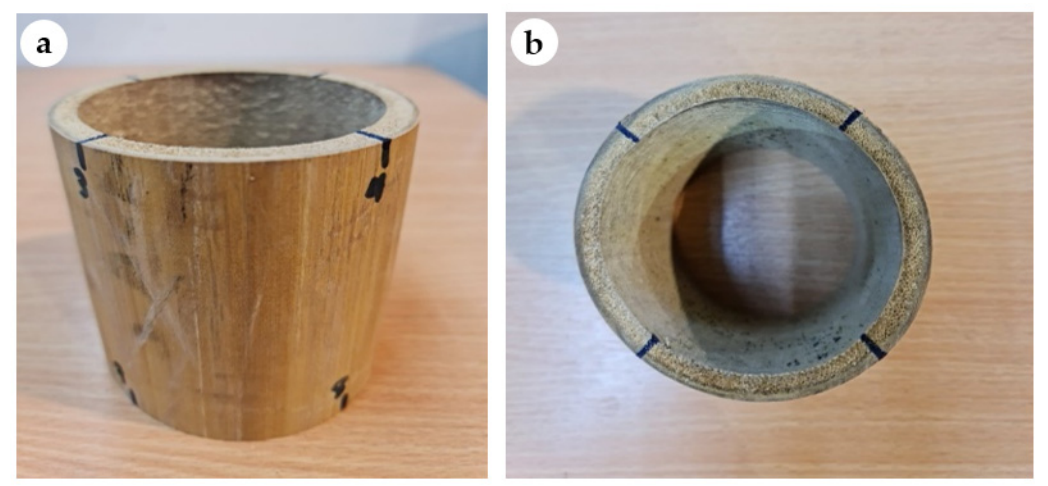

Figure 1. Typical bamboo specimen with 4 control points each at the top and bottom which are used to measure the corresponding geometric characteristics: (a) isometric view, and (b) top view.

\subsection{Shearing Test Using Universal Testing Machine (UTM)}

Samples are loaded using the set-up of ISO 22157 as shown in Figure 2. Tests are carried out on a suitable testing machine capable of measuring compression load with a precision of at least $1 \%$. The specimen is supported at its lower end over two opposing quadrants and loaded at its upper end over the other two opposing quadrants. Such a 
set-up will induce shear failure on four shear planes. It must be noted that the centers of the upper and lower shear plates shall be aligned with the vertical axis of the test machine. This must also be fixed so that they may not move relative to each other. The use of 2 steel rods serves this purpose.
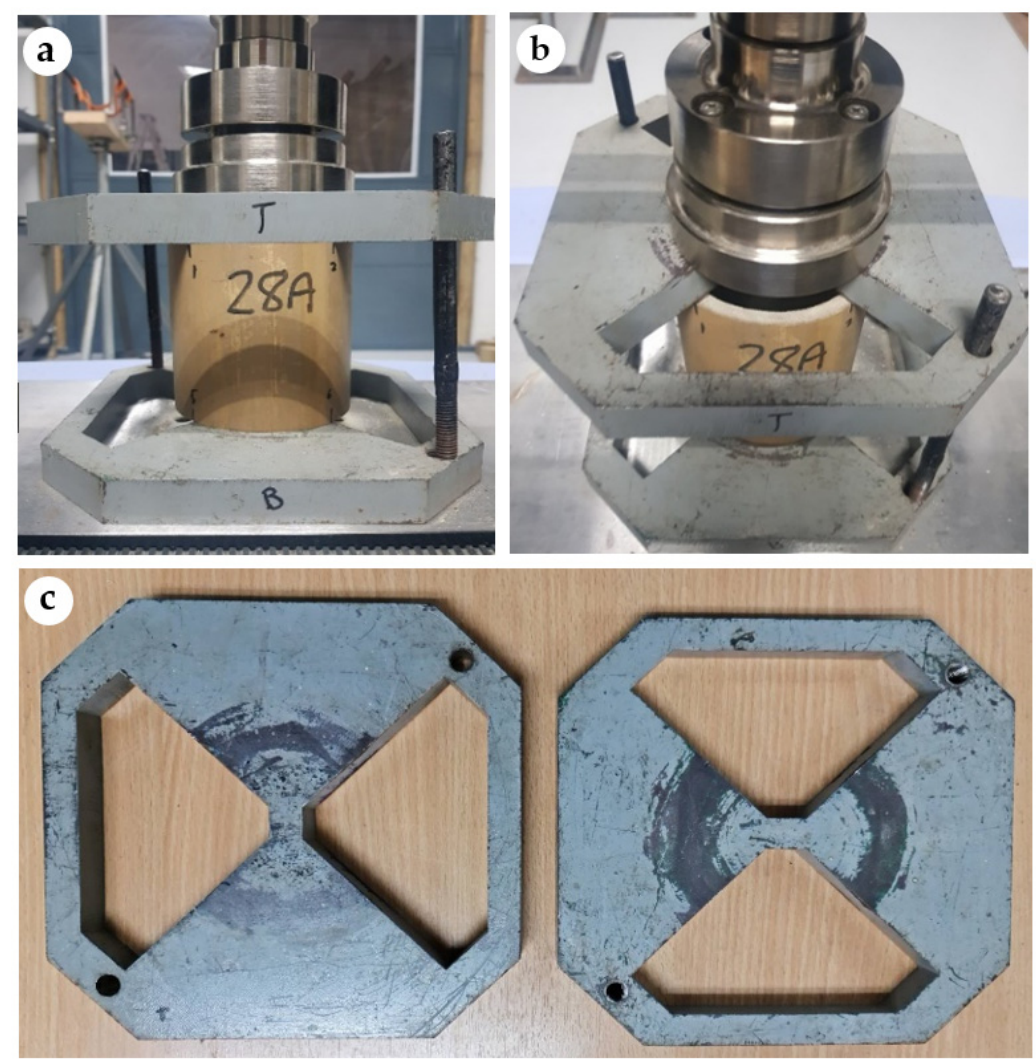

Figure 2. Shear testing of bamboo specimen: (a) test set-up front view, (b) test set-up top view, and (c) set of shearing plates capable of supporting the specimen on two opposing quadrants at the bottom and capable of loading the specimen on the other two opposing quadrants at the top.

After the pre-test measurements on the samples, the actual shearing test is performed. Samples are placed using the set-up shown in Figure 2, as discussed. The final quality control before testing is performed on this step. The ends of the culms are ensured to be smooth, parallel, and at right angles to the culm longitudinal axis. Specimens that will make both plates unparallel to each other are immediately discarded. A final check for possible defects such as cracks or holes is also performed. Specimens with defects are immediately discarded.

After the set-up is complete, a typical loading rate between $0.15 \frac{\mathrm{mm}}{\mathrm{min}}$ to $0.30 \frac{\mathrm{mm}}{\mathrm{min}}$ was applied such that the testing time was within $300 \pm 120 \mathrm{~s}$ based on ISO 22157-1 (2017). Tests that fail in less than $30 \mathrm{~s}$ are discarded from the analysis. Observe the test until failure is achieved. Record the load at failure as reflected on the Universal Testing Machine (UTM) software. Determine if the sample failed due to shear by visual inspection and cross-check with the load-displacement curve generated by the software. Mark the sample as a "filtered sample" if the sample failed due to shear. Discard the result if samples failed other than due to shear.

\subsection{Data Collection-Post-Testing}

Obtain a test piece for density and moisture content determination from the "filtered sample". Afterward, measure the length, width, and thickness of the test piece to determine the volume of the test piece. Weigh the test piece as well and record it as $m_{i}$. Thereafter, oven-dry the sample at $105^{\circ} \mathrm{C}$ for $24 \mathrm{~h}$. After $24 \mathrm{~h}$, the mass is recorded at regular intervals 
of not less than $2 \mathrm{~h}$. The oven-drying is complete when the difference between successive mass measurements does not exceed $0.5 \%$ of the measured mass. Weigh the oven-dry sample and record as $m_{o}$. Finally, compute for the moisture content and basic density. All measurements and test results are recorded using an excel sheet. Shear area, shear strength, moisture content, linear weight, and basic density are also computed for each bamboo specimen on a per species level.

\subsection{Method of Analysis and Declaration of Result}

The shear strength of bamboo parallel to fiber was calculated through the load at failure reflected on the Universal Testing Machine (UTM) and the summation of shear plane areas on the control points established. This is formally given on Equation (1) where $f_{v}$ is shear strength in $\mathrm{MPa}, t$ is the average thickness of the specimen at the control points, and $L$ is the length of the specimen at the control points.

$$
f_{v}=\frac{F_{L}}{\sum L t}
$$

Other physical properties such as the moisture content $(\omega)$, linear weight $(q)$, and basic density $(\rho)$ were also derived using ISO 22157-1 (2017). Moisture content can be determined by the oven-dry method and is given by Equation (2) where $\omega$ is the moisture content in $\%, m_{i}$ is the green weight of bamboo, and $m_{0}$ is the oven-dry weight of bamboo. The linear weight or the mass per unit length of the specimen is also given by Equation (3) where $q$ is the linear weight in $\frac{\mathrm{kg}}{\mathrm{m}}, m_{e}$ is the mass of the test piece at the green condition, and $L$ is the length of the test piece. Finally, for some scientific purposes and accurate comparison of reported values, basic density $(\rho)$ is most appropriate and this is determined from oven-dry mass and green volume since these will remain unchanged irrespective of environmental conditions [29]. Equation (4) shows the computation of the basic density $(\rho)$ in $\frac{\mathrm{kg}}{\mathrm{m}^{3}}$ where $m_{0}$ is the oven-dry weight of the test piece and $V$ is the volume of the green test piece.

$$
\begin{gathered}
\omega(\%)=\left[\frac{m_{i}-m_{0}}{m_{0}}\right] \times 100 \\
q=\frac{m_{e}}{L} \\
\rho=\frac{m_{0}}{V}
\end{gathered}
$$

ISO 12122-1 (2014) was used to evaluate the characteristic strength value of the test results [30]. Based on this standard, the 5th percentile evaluation should be used as the basis for the characteristic shear strength value. Characteristic value based on the 5th percentile value with $75 \%$ confidence was evaluated using the non-parametric data analyzed using AS/NZS 4063.2. This was done by ranking the test data and determining the 5th percentile of the ranked data. The 5 th percentile value with $75 \%$ confidence shall be evaluated using Equation (5). In this equation $X_{0.05,0.75}$ is referred as the characteristic value in $\frac{\mathrm{N}}{\mathrm{mm}^{2}}, X_{0.05}$ is the 5th percentile value of the sample in $\frac{\mathrm{N}}{\mathrm{mm}^{2}}, V$ is the coefficient of variation of the test data found by dividing the standard deviation of the sample and the mean value of the sample, $n$ is the size of the sample, and $k_{0.05,0.75}$ is a multiplier to give the 5 th percentile value with $75 \%$ confidence. The $k_{0.05,} 0.75$ multiplier is dependent on the number of specimens $(n)$ as summarized in Table 2. In this study, the $k_{0.05,0.75}$ multiplier used is 2.01 for $n=30$ and 1.85 for $n=100$.

$$
X_{0.05,0.75}=X_{0.05}\left(1-\frac{k_{0.05,0.75} V}{\sqrt{n}}\right)
$$


Table 2. $k_{0.05,0.75}$ Values-Use of non-parametric data analyzed using AS/NZS 4063.2 (ISO 12122-1).

\begin{tabular}{cc}
\hline Number of Specimens (n) & $k_{\mathbf{0 . 0 5 , 0 . 7 5}}$ \\
\hline 5 & - \\
10 & - \\
30 & 2.01 \\
50 & 1.94 \\
100 & 1.85 \\
$>100$ & 1.76 \\
\hline
\end{tabular}

$k_{0.05,0.75}$-multiplier to give the 5 th percentile value with $75 \%$ confidence.

Single-factor Analysis of Variance (ANOVA) was used to compare the mean of the test results and determine whether any of those means have statistically significantly different from each other. Students $t$-test was also used for comparison of individual bamboo species' comparability. In both statistical tests, a 95\% confidence level was used.

\section{Results and Discussion}

Figure 3 shows the typical shear failure patterns that are observed in this study. Most of the samples failed on either 1 or 2 shear failure planes- $64 \%$ of the tests failed on 1 shear failure plane while $34 \%$ of the tests failed on 2 simultaneous shear failure planes. Only $2 \%$ of the tests failed on 3 simultaneous shear failure planes while no sample failed on 4 simultaneous shear failure planes.
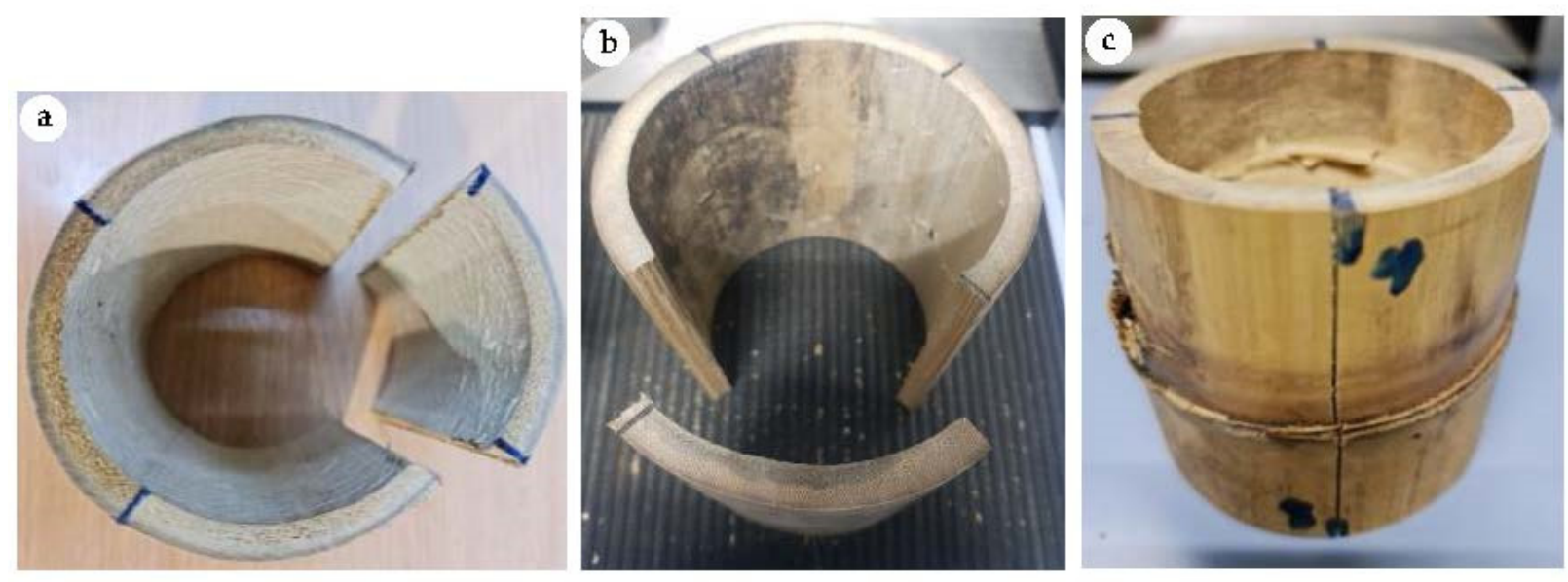

Figure 3. Typical shear failure patterns: $(\mathbf{a}, \mathbf{b})$ failure on 2 shear planes, and (c) failure on 1 shear plane.

\subsection{Geometric Characteristics and Other Physical Properties}

Geometric properties are measured using a digital vernier caliper with $0.5 \%$ precision. Consequently, the shear failure areas are computed based on the length and thickness measured at the specimen's control points. A summary of the geometric characteristics of the bamboo specimens used is given in Table 3. It is noted that the length of the specimen is dictated by the diameter and the thickness of the bamboo culm. Among all the species, the Bambusa vulgaris species constitutes the largest average shear area with $4382.4 \mathrm{~mm}^{2}$ while the least average shear area is $1672.2 \mathrm{~mm}^{2}$ of the Bambusa philippinensis species. The same observation is true for the thickness of the specimens wherein Bambusa vulgaris species has the highest average thickness of $11.64 \mathrm{~mm}$ while the same Bambusa philippinensis species has the lowest average thickness of $6.69 \mathrm{~mm}$. The other species have relatively the same average thickness, ranging from $7.53 \mathrm{~mm}$ to $7.98 \mathrm{~mm}$. A summary of the other physical properties with their corresponding Coefficient of Variation (COV) is also given in Table 4 . It can be inferred that the average moisture content $(\omega)$ of all the bamboo species ranges from $9.36-12.12 \%$. As such, bamboo specimens used in the test are considered as "air-dry" bamboo $(\omega=12 \pm 3 \%)$. Specimens are to be tested in "air-dry" 
conditions, or at the equilibrium moisture content $(\omega)$, at the locality where the bamboo is to be used [29]. It can also be observed that the heaviest bamboo species per linear length is the Bambusa vulgaris with an average mass per unit length $(q)$ of $2.29 \frac{\mathrm{kg}}{\mathrm{m}}$ while the lightest bamboo species per linear length is the Bambusa philippinensis with an average mass per unit weight $(q)$ of $1.03 \frac{\mathrm{kg}}{\mathrm{m}}$. As is evident in the table, the highest average basic density $(\rho)$ is Bambusa blumeana with $\rho=761.71 \frac{\mathrm{kg}}{\mathrm{m}^{3}}$ while the lowest average basic density $(\rho)$ is Bambusa vulgaris with $=561.31 \frac{\mathrm{kg}}{\mathrm{m}^{3}}$. It is noted that only the internode specimens are considered in the determination of basic density $(\rho)$ to increase the accuracy of volume measurements since it is easier to geometrically approximate the volume of internode specimens compared to specimens with nodes. The highest average COV is from linear weight results ( $C O V=0.275)$, followed by the basic density $(C O V=0.165)$, and then the moisture content $(\mathrm{COV}=0.111)$. Thus, we can deduce that the linear weight values have the highest level of dispersion from its corresponding mean values as compared to the values of basic density and moisture content.

Table 3. Summary of geometric characteristics of bamboo specimens for the 5 bamboo species considered.

\begin{tabular}{cccccc}
\hline \multicolumn{1}{c}{ Species } & \multicolumn{5}{c}{ All Specimens (Mean) } \\
\hline \multirow{2}{*}{ Scientific Name } & $\mathbf{n}$ & Length (L) & Diameter (D) & Thickness (t) & Area (A) \\
\cline { 3 - 6 } & & $\mathbf{m m}$ & $\mathbf{m m}$ & $\mathbf{m m}$ & $\mathbf{m m}^{\mathbf{2}}$ \\
\hline G. apus & 30 & 93.67 & 95.06 & 7.98 & 3030.8 \\
B. philippinensis & 30 & 62.57 & 63.34 & 6.69 & 1672.2 \\
B. vulgaris & 30 & 93.10 & 94.42 & 11.64 & 4382.4 \\
D. asper & 30 & 96.12 & 97.10 & 7.53 & 2921.2 \\
B. blumeana & 100 & 92.08 & 94.56 & 7.65 & 2831.8 \\
\hline
\end{tabular}

$\mathrm{n}$-number of samples, L-average length, $\mathrm{D}$ - -average diameter at top and bottom of the specimen, $\mathrm{t}$-average thickness of specimen at 8 control points, A-the average shear area of the specimens.

Table 4. Summary of other physical properties of bamboo specimens for the 5 bamboo species considered.

\begin{tabular}{|c|c|c|c|c|}
\hline \multirow{2}{*}{ Species } & \multicolumn{2}{|c|}{ All Specimens (Mean) } & \multicolumn{2}{|r|}{ Internode Specimens (Mean) } \\
\hline & $\mathbf{n}$ & Moisture Content $(\omega) \%$ & Linear Weight $(q) \mathrm{kg} / \mathrm{m}$ & Basic Density $(\rho) \mathrm{kg} / \mathrm{m}^{3}$ \\
\hline G. apus & 30 & $10.61(0.094)$ & $1.87(0.313)$ & $679.29(0.205)$ \\
\hline B. philippinensis & 30 & $11.20(0.137)$ & $1.03(0.256)$ & $685.23(0.070)$ \\
\hline B. vulgaris & 30 & $12.12(0.068)$ & $2.29(0.270)$ & $561.31(0.204)$ \\
\hline D. asper & 30 & $10.28(0.170)$ & $1.75(0.299)$ & $720.42(0.171)$ \\
\hline B. blumeana & 100 & $9.36(0.084)$ & $2.04(0.239)$ & $761.71(0.173)$ \\
\hline
\end{tabular}

$\mathrm{n}$-number of samples, $\omega$-moisture content in $\%, q$-mass per unit length in $\mathrm{kg} / \mathrm{m}, \rho$ - basic density in $\mathrm{kg} / \mathrm{m}^{3}$ (only measured for internode specimens). Numerical figures inside parentheses are equal to the coefficient of variation (COV).

\subsection{Shear Strength}

Figure 4 shows a graphical summary of the average shear strength parallel to fiber $\left(f_{v}\right)$ for each bamboo species. The error bars constituting the standard deviation for both positive and negative regions from the mean are also reflected. A summary of the statistical results is also given in Table 5. It can be observed that the bamboo species with the highest average shear strength are Bambusa blumeana with $f_{v}=11.44 \mathrm{Mpa}$. Following these species are Gigantochloa apus and Dendrocalamus asper species with $f_{v}=10.77 \mathrm{MPa}$ and $f_{v}=10.31 \mathrm{MPa}$, respectively. Finally, the bamboo species with the two lowest average shear strengths obtained in this study are Bambusa philippinensis and Bambusa vulgaris species with $f_{v}=9.68 \mathrm{MPa}$ and $f_{v}=9.23 \mathrm{MPa}$, respectively. Statistically, the bamboo species with the highest standard deviation is Bambusa blumeana with StDev = 3.174 MPa while the bamboo species with the lowest standard deviation is Bambusa philippinensis with $S t D e v=1.552 \mathrm{MPa}$. Consequently, these bamboo species also constitute the extreme values for the variance and COV. The Bambusa blumeana species has the highest variance and COV $($ Var $=10.073$ and COV $=0.278)$ while the Bambusa philippinensis species has the 
lowest variance and COV $(\operatorname{Var}=2.409$ and $C O V=0.160)$. This suggests that the values of shear strength $\left(f_{v}\right)$ has the highest level of variation for Bambusa blumeana species as compared to all other bamboo species.

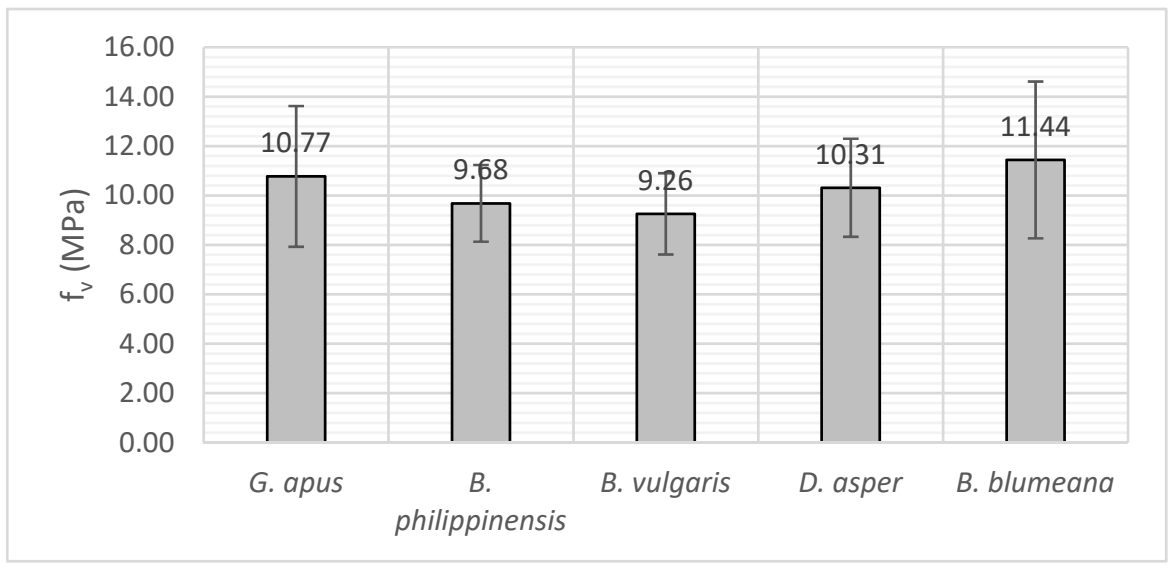

Figure 4. Average shear strength parallel to fiber $\left(f_{v}\right)$ with error bars corresponding to the standard deviation value $( \pm$ StDev) per bamboo species.

Table 5. Descriptive statistics of shear strength parallel to fiber test results, $f_{v}(\mathrm{MPa})$-All specimens.

\begin{tabular}{cccccccc}
\hline \multirow{2}{*}{ Species } & $\mathbf{9}$ & \multicolumn{9}{c}{ All Specimens } \\
\cline { 2 - 8 } & $\mathbf{n}$ & $f_{v}$, Min & $f_{v}$, Max & $f_{v}$, Mean & StDev & VAR & COV \\
\hline G. apus & 30 & 5.3 & 15.81 & 10.77 & 2.849 & 8.118 & 0.264 \\
B. philippinensis & 30 & 6.18 & 13.14 & 9.68 & 1.552 & 2.409 & 0.160 \\
B. vulgaris & 30 & 5.88 & 12.19 & 9.26 & 1.644 & 2.704 & 0.178 \\
D. asper & 30 & 7.26 & 15.24 & 10.31 & 1.985 & 3.940 & 0.192 \\
B. blumeana & 100 & 4.15 & 16.50 & 11.44 & 3.174 & 10.073 & 0.278 \\
\hline
\end{tabular}

$\mathrm{n}$-number of samples, $f_{v}$-shear strength parallel to fiber, StDev—standard deviation based on the sample, VAR—variance based on the sample, COV—coefficient of variation taken as StDev over mean.

Another aspect of this research is the verification of the effect of nodes on the resulting shear strength parallel to fiber $\left(f_{v}\right)$. Table 6 summarizes the statistical analysis between the internode specimens and specimens with nodes. It can be observed that the range of difference of the average shear strength $\left(f_{v}\right)$ values between internode and specimens with a node are $0.24-1.02 \mathrm{MPa}$. Hypothesis testing through unpaired $t$-test method is used to determine whether there is a statistical difference between the reported shear strength $\left(f_{v}\right)$ values of the internode specimens and specimens with node. The initial hypothesis is given by $H_{0}: \mu_{1}=\mu_{2}$, meaning the mean difference between two samples approaches zero $\left(\mu_{D}=0\right)$ while the alternative hypothesis is given by $H_{A}: \mu_{1} \neq \mu_{2}$, implying that there is a significant difference between the mean of the two samples. A $p$-value of $<0.05$ signifies that we can reject the initial hypothesis and conclude the alternative. Based on Table 6, $p$-values $>0.05$ for all bamboo species indicate that we cannot reject the initial hypothesis. Thus, the difference in the mean values of the two groups (internode specimens and specimens with node) is not great enough to reject the possibility that the difference is due to random sampling variability. In other words, there is not a statistically significant difference between the groups of internode specimens and specimens with nodes. It is noted that only the bamboo culms, which have matching internode specimens and specimens with nodes, are included in this statistical test. 
Table 6. Shear strength parallel to fiber test results, $f_{v}(M P a)$-Internode specimen vs. specimen with node.

\begin{tabular}{cccccccc}
\hline \multirow{2}{*}{ Species } & \multicolumn{3}{c}{ Internode Specimen } & \multicolumn{3}{c}{ Specimen with Node } & $p$-Value ${ }^{\mathbf{1}}$ \\
\cline { 2 - 7 } & $\mathbf{n}$ & $f_{v}$, Mean & COV & $\mathbf{n}$ & $f_{v}$, Mean & COV & \\
\hline G. apus & 15 & 11.13 & 0.201 & 15 & 10.41 & 0.326 & 0.5012 \\
B. philippinensis & 15 & 9.98 & 0.150 & 15 & 9.38 & 0.170 & 0.3018 \\
B. vulgaris & 15 & 9.37 & 0.159 & 15 & 9.14 & 0.200 & 0.7006 \\
D. asper & 15 & 9.91 & 0.160 & 15 & 10.72 & 0.214 & 0.2720 \\
B. blumeana & 30 & 12.74 & 0.213 & 30 & 12.07 & 0.210 & 0.3236 \\
\hline
\end{tabular}

$\mathrm{n}$-number of samples, $f_{v}$-shear strength parallel to fiber, COV-coefficient of variation taken as StDev over mean, $p$-value- $p$-value from two-tail unpaired $t$-test assuming unequal variance. ${ }^{1} p$-value $>0.05$ signifies the non-rejection of null hypothesis $H_{0}: \mu_{1}=\mu_{2}$ meaning there is not a statistically significant difference between the two input groups considered.

According to (ISO 12122-1), the basis for the shear strength parallel to fiber $\left(f_{v, c}\right)$ should be the 5 th percentile of the test report values. Figure 5 shows the graphical representation of the characteristic shear strength parallel to fiber $\left(f_{v, c}\right)$ for all bamboo species used in this study. It can be observed that the bamboo species with the highest characteristic shear strength $\left(f_{v, c}\right)$ is the Bambusa philippinensis species with $f_{v, c}=7.26 \mathrm{MPa}$. This is followed by Dendrocalamus asper species with $f_{v, c}=6.98 \mathrm{MPa}$. Dendrocalamus asper species is followed by Bambusa vulgaris species with $f_{v, c}=6.46 \mathrm{MPa}$. Finally, the bamboo species with the two lowest characteristic strengths are Bambusa blumeana and Gigantochloa apus species with $f_{v, c}=5.15 \mathrm{MPa}$ and $f_{v, c}=5.11 \mathrm{MPa}$, respectively.

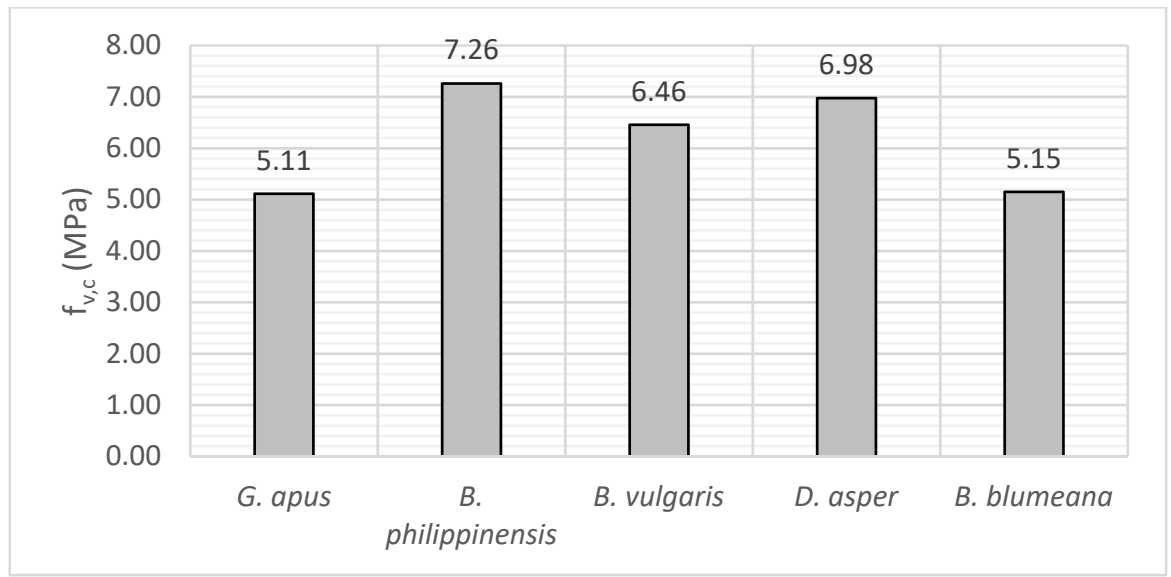

Figure 5. Characteristic shear strength parallel to fiber $\left(f_{v, c}\right)$ per bamboo species.

It can be remarked that there is no direct relationship between the average shear strength $\left(f_{v}\right)$ vs. the characteristic shear strength $\left(f_{v, c}\right)$. This is reasonable since the characteristic shear strength is "rank" sensitive, which implies that any low-ranking shear strength value $\left(f_{v}\right)$ obtained might directly pull the characteristic value down. An exceptionally stark correlation, noticed with the results of characteristic shear strength $\left(f_{v, c}\right)$, is the COV of the average shear strength $\left(f_{v}\right)$. It is noted that the bamboo species with low COV resulted in higher characteristic shear strength $\left(f_{v, c}\right)$ values relative to bamboo species which has higher COV. Table 7 summarizes the evaluation of the 5 th percentile value with $75 \%$ confidence using non-parametric data analyzed using AS/NZS 4063.2 as advised on (ISO 12122-1). 
Table 7. Evaluation of 5th percentile value with $75 \%$ confidence-Use of non-parametric data analyzed using AS/NZS 4063.2.

\begin{tabular}{cccccc}
\hline & \multicolumn{5}{c}{ All Specimens } \\
\cline { 2 - 6 } Species & $\mathbf{n}$ & $\mathbf{C O V}$ & 5th Percentile & Multiplier & Characteristic Value \\
\cline { 4 - 6 } & & & $\mathbf{X}_{\mathbf{0 . 0 5}} \mathbf{( M P a )}$ & $\mathbf{k}_{\mathbf{0 . 0 5 , 0 . 7 5}}$ & $\mathbf{X}_{\mathbf{0 . 0 5 , 0 . 7 5}} \mathbf{( M P a )}$ \\
\hline G. apus & 30 & 5.264 & 5.66 & 2.01 & 5.11 \\
B. philippinensis & 30 & 0.160 & 7.71 & 2.01 & 7.26 \\
B. vulgaris & 30 & 0.178 & 6.91 & 2.01 & 6.46 \\
D. asper & 30 & 0.192 & 7.51 & 2.01 & 6.98 \\
B. blumeana & 100 & 0.278 & 5.43 & 1.85 & 5.15 \\
\hline
\end{tabular}

Method of evaluation is based on Annex A.2.2 of ISO 12122-1:2014. n-number of samples, COV—coefficient of variation taken as StDev over mean, $\mathrm{X}_{0.05}$ - 5 th percentile value of the shear strength parallel to fiber results, $\mathrm{k}_{0.05,0.75}$-multiplier to give the 5 th percentile value with $75 \%$ confidence, $\mathrm{X}_{0.05,0.75}$-resulting characteristic value in MPa.

\subsection{Comparative Analysis Using ANOVA and t-Test}

Single-factor Analysis of Variance (ANOVA) is used to determine whether the shear strength $\left(f_{v}\right)$ values are comparable across all the bamboo species used in this research. Table 8 summarizes the statistical results comparing the shear strength values $\left(f_{v}\right)$ for all groups. Based on the table, $F_{\text {stat }}=5.4712$ while the $F_{\text {crit }}=2.4136$, which indicates that the $F_{\text {stat }}$ is within the critical or rejection region. This is validated by the $p$-value result which has a value $<0.0001$. From these results, we can conclude that the difference in the mean values of all groups is greater than would be expected by chance. Thus, there is a statistically significant difference between the input groups $(p<0.0001)$.

Table 8. Analysis of variance (ANOVA) results.

\begin{tabular}{|c|c|c|c|c|c|c|}
\hline Summary & & & & & & \\
\hline Groups & Count & Sum & Average & Variance & & \\
\hline Gigantochloa apus & 30 & 323.172 & 10.772 & 8.118 & & \\
\hline Bambusa philippinensis & 30 & 290.471 & 9.682 & 2.409 & & \\
\hline Bambusa vulgaris & 30 & 277.660 & 9.255 & 2.704 & & \\
\hline Dendrocalamus asper & 30 & 309.403 & 10.313 & 3.940 & & \\
\hline Bambusa blumeana & 100 & 1143.687 & 11.437 & 10.073 & & \\
\hline \multicolumn{7}{|l|}{ Anova } \\
\hline Source of Variation & SS & $\mathrm{df}$ & MS & F stat & $p$-value ${ }^{1}$ & F crit \\
\hline Between Groups & 152.1986 & 4 & 38.0496 & 5.4712 & 0.000325883 & 2.4136 \\
\hline Within Groups & 1495.2231 & 215 & 6.9545 & & & \\
\hline Total & 1647.4217 & 219 & & & & \\
\hline
\end{tabular}

Count-number of samples, SS -the sum of squares, df-degrees of freedom, MS-mean sum of squares taken as SS over df, F stat-F-value taken as MS (Between Groups) over MS (Within Groups), $p$-value— $p$-value from single-factor analysis of variance (ANOVA), F crit—-the critical value of $\mathrm{F}$ that determines the significance of the group of variables. ${ }^{1} p$-value $<0.05$ signifies the rejection of null hypothesis $H_{0}$ : $\mu_{1}=\mu_{2}=\mu_{3 . n}$ (where $\mathrm{n}$ is the number of groups) meaning there is a statistically significant difference between the input groups considered.

Because of the previous conclusion, that the shear strength $\left(f_{v}\right)$ values are not comparable for all bamboo species, there is a motivation to compare the bamboo species independently using an unpaired $t$-test assuming unequal variance between two groups. A total of 10 relationships are considered in this statistical analysis. Table 9 summarizes the statistical results using the $t$-test method. For $p$-values $<0.05$, we again conclude that there is a statistically significant difference between the two groups considered. Otherwise, the two groups considered are comparable. A result of Table 9 formulates the matrix of comparison, as shown in Table 10, to easily depict the relationships between bamboo species in terms of shear strength $\left(f_{v}\right)$ values. Based on this table, $50 \%$ of the 10 possible relationships produced comparable relationships. The following bamboo species' relationships yielded comparable shear strength $\left(f_{v}\right)$ values: (1) Gigantochloa apus and Bambusa 
philippinensis; (2) Gigantochloa apus and Dendrocalamus asper; (3) Gigantochloa apus and Bambusa blumeana; (4) Bambusa philippinensis and Bambusa vulgaris; (5) Bambusa philippinensis and Dendrocalamus asper.

Table 9. Multiple comparisons using $t$-test for all groups.

\begin{tabular}{|c|c|c|c|c|c|}
\hline \multirow[b]{2}{*}{ Species } & \multirow[b]{2}{*}{ Comparison } & \multicolumn{3}{|c|}{$t$-Test Parameters } & \multirow[b]{2}{*}{$p$-Value ${ }^{1}$} \\
\hline & & df & t Stat & $\begin{array}{c}\text { t Crit } \\
\text { (Two-Tail) }\end{array}$ & \\
\hline \multicolumn{6}{|l|}{ G. apus } \\
\hline & B. philippinensis & 45 & 1.840 & 2.014 & 0.072 \\
\hline & B. vulgaris & 46 & 2.526 & 2.013 & 0.015 \\
\hline & D. asper & 52 & 0.724 & 2.007 & 0.472 \\
\hline & B. blumeana & 52 & -1.090 & 2.007 & 0.281 \\
\hline \multicolumn{6}{|c|}{ B. philippinensis } \\
\hline & B. vulgaris & 58 & 1.034 & 2.002 & 0.305 \\
\hline & D. asper & 55 & -1.372 & 2.004 & 0.176 \\
\hline & B. blumeana & 101 & -4.124 & 1.984 & $7.664 \times 10^{-5}$ \\
\hline \multicolumn{6}{|c|}{ B. vulgaris } \\
\hline & D. asper & 56 & -2.248 & 2.003 & 0.029 \\
\hline & B. blumeana & 95 & -4.993 & 1.985 & $2.689 \times 10^{-6}$ \\
\hline \multicolumn{6}{|l|}{ D. asper } \\
\hline & B. blumeana & 77 & -2.332 & 1.991 & 0.022 \\
\hline $\begin{array}{l}\text { df-degrees of } \\
\text { determines the s } \\
\text { ignifies the reje } \\
\text { he two input gr } \\
\text { groups consider }\end{array}$ & $\begin{array}{l}\text { stat-resulting } \\
\text { of the two group } \\
\text { ll hypothesis } H_{0} \text { : } \\
\text { idered. Otherwise }\end{array}$ & fron & $\begin{array}{l}\text { tatistical } t \\
\text { de-p-valu } \\
\text { here is a st } \\
\text { ically sign }\end{array}$ & $\begin{array}{l}\mathrm{t} \text { crit-the } \mathrm{cr} \\
\mathrm{m} \text { statistical } t \text { - } \\
\text { ically significar } \\
\mathrm{nt} \text { difference be }\end{array}$ & $\begin{array}{l}\text { al value of } \mathrm{t} \text { tha } \\
{ }^{1} p \text {-value }<0.0 \\
\text { lifference betwee } \\
\text { een the two inpu }\end{array}$ \\
\hline
\end{tabular}

Table 10. Comparison matrix for all groups.

\begin{tabular}{|c|c|c|c|c|c|}
\hline & G. apus & B. philippinensis & B. vulgaris & D. asper & B. blumeana \\
\hline G. apus & & $\mathrm{C}$ & $\mathrm{NC}$ & $\mathrm{C}$ & $\mathrm{C}$ \\
\hline B. philippinensis & & & C & C & NC \\
\hline B. vulgaris & & & & $\mathrm{NC}$ & NC \\
\hline D. asper & & & & & $\mathrm{NC}$ \\
\hline B. blumeana & & & & & \\
\hline
\end{tabular}

C-Comparable; NC-Not Comparable. The background color signifies that relationship between 2 bamboo species considered is either: not possible or already defined (C or NC).

\subsection{Correlation Models}

Pearson's correlation coefficients ( $\mathrm{r}$ ) were calculated to find the correlation between the bamboo culm geometry (length, diameter, and thickness), shear area (A), basic density $(\rho)$, moisture content $(\omega)$, and shear strength $\left(f_{v}\right)$. Three levels of correlation were specified (i.e., strong for $r>0.5$; moderately strong for $0.3<r<0.5$; weak for $r<0.3$ ). This regression coefficient represents the mean change in the dependent variable for each unit change in an independent variable when you keep all the other independent variables constant. Linear and multiple linear regressions were performed to further assess the relationships between the bamboo culm geometry and physical properties to the shear strength of bamboo. The performance of the model was determined based on its $r^{2}$ value. The $r^{2}$ parameter represents the percentage of the variations that are described by the independent variable $\left(f_{v}\right)$. Values of $r^{2}$ that are closer to 1 indicates that the model obtained represents more of the data points.

Table 11 displays the linear-model parameter values with the data obtained in this study. It must be noted that only models that are statistically significant with a $p$-value $<0.05$ are shown in the table. Moreover, the regression models are differentiated per parameter for 
each bamboo species used in this study. Based on the results, there are 8 models which depicted a strong correlation between a physical property of bamboo culms and its shear strength $\left(f_{v}\right)$. There were 3 models that came from moisture content $(\omega)$ vs. shear strength $\left(f_{v}\right)$ while the other 5 models came from basic density $(\rho)$ vs. shear strength $\left(f_{v}\right)$. This inference indicates that there is a consistently strong correlation between the basic density $(\rho)$ and shear strength $\left(f_{v}\right)$ for all the bamboo species, while moisture content $(\omega)$ parameter vs. shear strength $\left(f_{v}\right)$ indicates a strong correlation but is relatively inconsistent across the bamboo species used in this study. As for the other physical parameters, such as the geometric characteristics of the bamboo culms and the unit weight per linear meter of the bamboo samples, there is a weak or no significant correlation found. From this, we can deduce that shear strength $\left(f_{v}\right)$ is relatively independent of the geometric properties of bamboo specimens, including the effective shear area. Finally, all model significance for the regression models shown in Table 11 is $<0.05$, which indicates that a useful linear relationship exists between the considered parameters. This further validates the obtained linear regression models.

Table 11. Linear-Model Parameter Values for Shear Strength Parallel to Grain $\left(f_{v}\right)$.

\begin{tabular}{cccc}
\hline Source & Species & Equation & $\mathbf{R}^{\mathbf{2}}$ \\
\hline $\begin{array}{c}\text { This study regression models. } \\
\text { (Individual species) }\end{array}$ & & & \\
& G. apus & $f_{v}=-1.527 \omega+26.973$ & 0.284 \\
& G. apus & $f_{v}=0.012 \rho+2.689$ & 0.598 \\
& B. philippinensis & $f_{v}=-0.629 \omega+16.727$ & 0.386 \\
B. philippinensis & $f_{v}=0.017 \rho-1.844$ & 0.306 \\
B. vulgaris & $f_{v}=-1.388 \omega+26.074$ & 0.490 \\
& B. vulgaris & $f_{v}=0.009 \rho+4.110$ & 0.519 \\
D. asper & $f_{v}=0.008 \rho+4.380$ & 0.353 \\
& B. blumeana & $f_{v}=0.012 \rho+2.902$ & 0.413
\end{tabular}

Only the correlation models that are statistically significant with a model significance of $<0.05$ in the regression analysis are shown. $\omega$-moisture content in $\%, \rho$ - basic density in $\mathrm{kg} / \mathrm{m}^{3}, \mathrm{R}^{2}$-coefficient of determination.

One of the main motivations of this research is to come up with correlations between the physical properties of bamboo vs. shear strength $\left(f_{v}\right)$, irrespective of the bamboo species. This will be particularly useful for preliminary estimation of shear strength $\left(f_{v}\right)$ values using the physical properties of other bamboo species which are not included in this study. It can be observed that the basic density $(\rho)$ values have a strong correlation with shear strength $\left(f_{v}\right)$ values for all bamboo species. Thus, a single general model is developed using the basic density $(\rho)$ to predict the shear strength $\left(f_{v}\right)$. Figure 6 distinctly shows the scatter plot of basic density $(\rho)$ with shear strength $\left(f_{v}\right)$ for each bamboo species, which gave a strong correlation between the said parameters. In this case, the basic densities $(\rho)$ of all the bamboo species are considered predictors of their corresponding shear strength $\left(f_{v}\right)$ values. A linear trendline is then fitted to the formulated scatter plot using XY pair basic density $(\rho)$ and the shear strength $\left(f_{v}\right)$. The resulting linear regression model is likewise shown in Equation (6) where $(\rho)$ is the basic density in $\mathrm{kg} / \mathrm{m}^{3}$ and $\left(f_{v}\right)$ is the shear strength parallel to fiber in MPa. This model has an $r$ value $=0.6916$ which is relatively strong. Finally, the same trendline using the first model is replicated to develop the second linear regression model. However, the y-intercept is set to zero to further simplify the model in the form of a ratio. The same parameters are used: basic density $(\rho)$ in $\mathrm{kg} / \mathrm{m}^{3}$ and the shear strength $\left(f_{v}\right)$ in MPa. The resulting linear model is shown in Figure 7 and defined in Equation (7). This model has an $r$ value $=0.9872$ which is strong.

$$
\begin{gathered}
f_{v}=0.124 \rho+2.3903 \\
f_{v}=0.016 \rho
\end{gathered}
$$




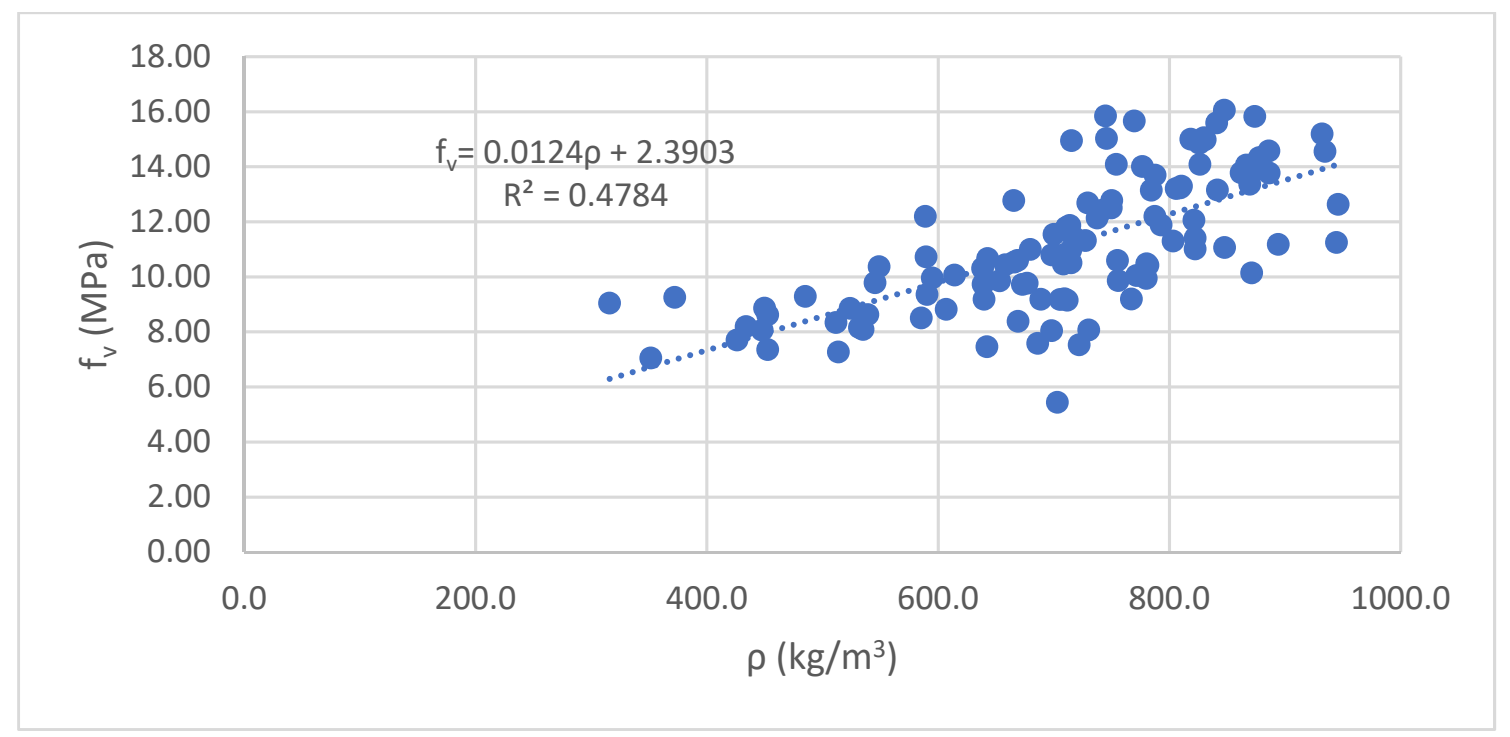

Figure 6. Basic density $(\rho)$ vs. shear strength $\left(f_{v}\right)$ linear regression model 1 (form: $y=m x+b$ as shown in Equation (6)).

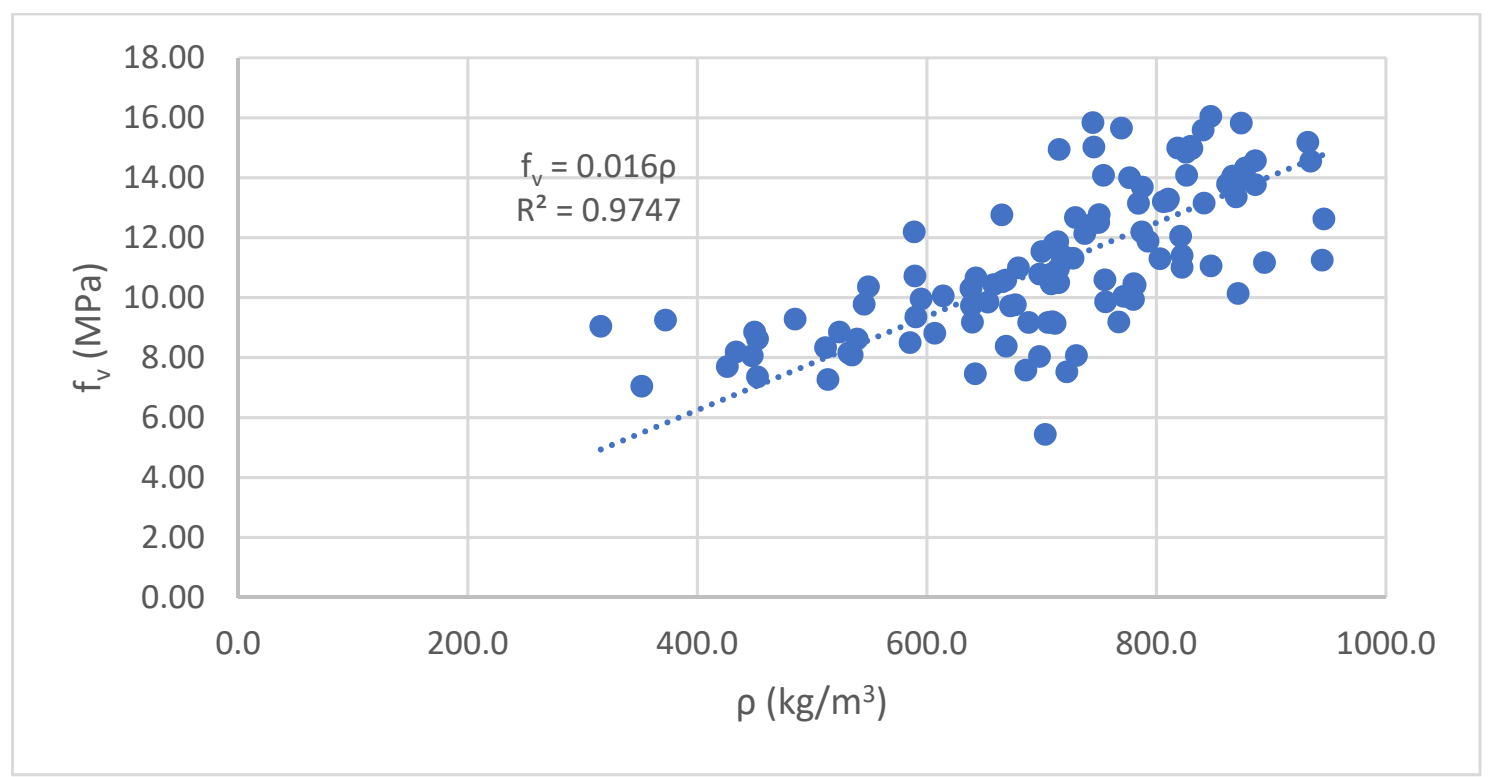

Figure 7. Basic density $(\rho)$ vs. shear strength $\left(f_{v}\right)$ linear regression model 2 (form: $y=m x$ as shown in Equation (7)).

A correlation comparison on a per species level is done by utilizing all the correlations obtained to predict shear strength $\left(f_{v}\right)$ using the basic density $(\rho)$. These correlations are also compared to an existing correlation obtained by (Janssen, 1981). The method of comparison is done by using the percent error parameter. Computed shear strength $\left(f_{v}\right)$ values, based on the existing and obtained models, are compared to the actual shear strength $\left(f_{v}\right)$ values, based on test report data, to get the percent error. It must be noted that only the internode specimens' data points are used since this specimen group has more accuracy in basic density $(\rho)$ approximation. Table 12 summarizes the percent error for the 2 models obtained in this study using the actual test results on a per species level. It can be observed that the range of average percent error in (Janssen, 1981) model for all bamboo species is from $29.03 \%-46.55 \%$ with the highest percent error $(46.55 \%)$ resulting from Bambusa philippinensis species with the lowest percent error $(29.03 \%)$ resulting from Bambusa blumeana species. The range of percent error correlating shear strength $\left(f_{v}\right)$ and basic density $(\rho)$ (Models 1 and 2) obtained in this study is from $8.83 \%-14.61 \%$ The highest percent error from Models 1 and 2 is $14.61 \%$ resulting from Dendrocalamus asper species 
while the lowest percent error $8.83 \%$ resulting from Gigantochloa apus species. A rather more straightforward comparison is by using the average percent error for all the bamboo species. The highest average percent error is from the model by (Janssen, 1981) with 36.0\%. This is followed by Models 2 and 1, which yielded an average percent error of $12.8 \%$ and $11.8 \%$, respectively. It can be concluded that the obtained correlation models are better predictors of shear strength $\left(f_{v}\right)$ values compared to the correlation made by (Janssen, 1981). A disparity of about $24 \%$ is observed from the model made by (Janssen, 1981) to the best model obtained in this study (Model 1). Because of these results, the obtained models are hereby recommended as a predictor tool to determine the shear strength $\left(f_{v}\right)$ values using only the physical properties of bamboo, which is the basic density $(\rho)$.

Table 12. Percent error using obtained correlation (Model 1 and Model 2) and existing correlation vs. actual data.

\begin{tabular}{|c|c|c|c|}
\hline \multirow{4}{*}{ Species } & \multicolumn{3}{|c|}{$\%$ Error (Average) } \\
\hline & \multicolumn{2}{|c|}{ Obtained $^{1}$} & \multirow{2}{*}{$\begin{array}{l}\text { Existing Study } \\
\text { (Janssen, 1981) }\end{array}$} \\
\hline & Model 1 & Model 2 & \\
\hline & $f_{v}=0.0124 \rho+2.3903$ & $f_{v}=0.016 \rho$ & $f_{v}=0.021 \rho$ \\
\hline G. apus & 8.83 & 10.64 & 29.03 \\
\hline B. philippinensis & 13.59 & 13.56 & 46.55 \\
\hline B. vulgaris & 8.87 & 11.01 & 25.90 \\
\hline D. asper & 13.61 & 14.61 & 44.23 \\
\hline B. blumeana & 14.21 & 14.17 & 34.28 \\
\hline Average & 11.8 & 12.8 & 36.0 \\
\hline
\end{tabular}

\subsection{Comparison with Other Literature}

The average shear strength $\left(f_{v}\right)$ determined for each bamboo species used in this research is summarized in Table 13, together, with the average values for basic density $(\rho)$ and moisture content $(\omega)$. Greater emphasis on the average shear strength $\left(f_{v}\right)$ is given on this table so the average shear strength values for different bamboo species are also given on the table for comparison. However, it must be noted that no general average shear strength $\left(f_{v}\right)$ is declared for all the bamboo groups in this study since based on the single factor ANOVA results, the obtained values for $\left(f_{v}\right)$ are not statistically comparable with each other. At initial assessment, obtained values for all parameters listed on the table are comparable with the obtained data on available literature. There is no outlier data from the test results as almost all resulting values are within the range of the values on available literature. A rather straightforward comparison of Bambusa blumeana species can be deduced from this table through the study of Salzer et al. [19] where they attained an average shear strength given by $f_{v}=8.8 \mathrm{MPa}$. The average shear strength for the same bamboo species as obtained on this research is given by $f_{v}=11.4 \mathrm{MPa}$. About 2.6 MPa deviation is calculated, which is about a $30 \%$ increase from the values obtained by Cantos et al. [24]. Though the percent deviation is relatively high, it must be noted that a total of 100 samples failing in shear are used in this research for this specific bamboo species, as compared to 13 samples from the previously cited research.

The characteristic shear strength $\left(f_{v, c}\right)$ values determined for each bamboo species used in this research are summarized in Table 14 . This is readily contrasted to the declared characteristic value of Bambusa blumeana from the study by Salzer et al. [1] where they obtained an $\left(f_{v, c}=5.0 \mathrm{MPa}\right)$. Based on the results of this study, the obtained $\left(f_{v, c}=5.2 \mathrm{MPa}\right)$ for Bambusa blumeana from Tarlac species is almost equal to the previously cited study. This constitutes to roughly $4 \%$ deviation, which is remarkable. 
Table 13. Comparison of average shear stress and physical properties with related literature.

\begin{tabular}{|c|c|c|c|c|}
\hline \multirow{2}{*}{ Source } & \multirow{2}{*}{ Species } & $\rho$ & $\omega$ & $f_{v}$ \\
\hline & & $\mathrm{kg} / \mathrm{m}^{3}$ & $\%$ & MPa \\
\hline \multicolumn{5}{|l|}{ This study strength } \\
\hline & G. apus & 679 & 11 & 10.8 \\
\hline & B. philippinensis & 685 & 11 & 9.7 \\
\hline & B. vulgaris & 561 & 12 & 9.3 \\
\hline & D. asper & 720 & 10 & 10.3 \\
\hline & B. blumeana & 762 & 9 & 11.4 \\
\hline Cantos et al., 2019 & B. blumeana & - & - & 8.8 \\
\hline Gauss et al., 2019 & P. edulis (full culm) & 810 & $7-10$ & 18.1 \\
\hline Salzer et al., 2018 & B. blumeana (Philippines) & 570 & - & 8.8 \\
\hline Latif et al., 1992 & B. blumeana (Malaysia) & - & - & 4.8 \\
\hline Correal et al., 2010 & G. angustifolia (Colombia) & - & - & 7.6 \\
\hline Hernandez et al., 2010 & G. aculeata (Mexico) & - & - & 8.3 \\
\hline \multirow[t]{2}{*}{ Ordonez et al., 2014} & G. amplexifiolia (Mexico) & - & - & 5.8 \\
\hline & G. veluntina (Mexico) & - & - & 5.7 \\
\hline \multirow[t]{2}{*}{ Sompoh et al., 2013} & B. blumeana (Thailand) & - & 11 & 12.3 \\
\hline & B. bambos (Thailand) & - & 19 & 6.4 \\
\hline Akinbade et al., 2019 & G. angustifolia & 896 & 14 & 15.1 \\
\hline Deng et al., 2016 & P. edulis & 655 & $8-12$ & 11.8 \\
\hline Dixon et al., 2015 & P. edulis & 400 & 4 & - \\
\hline Huang et al., 2015 & P. edulis & - & 12 & 12.9 \\
\hline Oka et al., 2014 & G. atroviolacea & - & $12-16$ & 7.7 \\
\hline Lozano et al., 2010 & G. angustifolia (Colombia) & - & - & 7.10-7.47 \\
\hline
\end{tabular}

Table 14. Comparison of characteristic shear strength value $\left(f_{v, c}\right)$ with related literature.

\begin{tabular}{ccc}
\hline Source & Species & $f_{v, c}$ \\
This study Characteristic & & $\mathbf{M P a}$ \\
Strength & G. apus & \\
& B. philippinensis & 5.1 \\
& B. vulgaris & 7.3 \\
& D. asper & 6.5 \\
Salzer et al. & B. blumeana & 7.0 \\
& B. blumeana & 5.2 \\
\hline
\end{tabular}

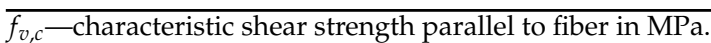

Finally, the average shear strength $\left(f_{v}\right)$ values determined for each bamboo species used in this research is compared to the average shear strength $\left(f_{v}\right)$ of some of the common timber species in the Philippines as given in Table 15 [23,24]. The general range of the average shear strength $\left(f_{v}\right)$ values is $9.3-11.4 \mathrm{MPa}$, which is likewise comparable with the shear strength values of some timber species. It can be inferred that, unlike some wood species, the lower limit of the average shear strength for the bamboo species used in this research is only 9.3 $\mathrm{MPa}$, which is well above the 3.3 MPa value for Kapor timber species. Though there are upper-tier shear strength values (10-12 MPa) for some timber species which exceeded some of the bamboo species used in this research, the factor of material sustainability must likewise be factored in. Thus, positioning the bamboo species as an undeniably better alternative material for timber in terms of shear. 
Table 15. Comparison of average shear strength value $\left(f_{v}\right)$ with local timber species.

\begin{tabular}{|c|c|c|}
\hline \multirow{2}{*}{ Source } & \multirow{2}{*}{ Species } & $f_{v}$ \\
\hline & & MPa \\
\hline \multicolumn{3}{|c|}{ This study average strength } \\
\hline & G. apus & 10.8 \\
\hline & B. philippinensis & 9.7 \\
\hline & B. vulgaris & 9.3 \\
\hline & D. asper & 10.3 \\
\hline & B. blumeana & 11.4 \\
\hline & General & $9.3-11.4$ \\
\hline \multicolumn{3}{|c|}{ Bello et al., 1997 [31] } \\
\hline & Balobo & 9.3 \\
\hline & Amugis & 10.0 \\
\hline & Anabiong & 5.3 \\
\hline & Anang & 8.5 \\
\hline & Balete & 7.5 \\
\hline & Antipolo & 4.0 \\
\hline & Balakat & 10.1 \\
\hline & Kato & 8.6 \\
\hline & Ulaian & 9.7 \\
\hline \multicolumn{3}{|c|}{ Valencia et al., 1921 [32] } \\
\hline & Tangile & 7.1 \\
\hline & Apitong & 8.2 \\
\hline & Guijo & 9.7 \\
\hline & Gisok & 12.6 \\
\hline & Lumbayan & 7.6 \\
\hline & Kapor & 3.3 \\
\hline
\end{tabular}

$f_{v}$-average shear strength parallel to fiber in MPa.

\subsection{Other Analysis}

The nature of shear strength parallel to fiber variation for Bambusa blumeana species was examined, as well. Only this species is considered since it is the only bamboo species with $n=100$ samples. For this analysis, the Minitab ${ }^{\circledR}$ version 18.1 was utilized. The 100 data sets were initially used for the normality tests where the null hypothesis is given by $H_{0}$ : Data follow a normal distribution, and the alternative hypothesis is given by $H_{A}$ : Data do not follow a normal distribution. The common normality tests yielded the following results: (1) Anderson-Darling (AD stat $=1.757, p$-value $<0.005)$, (2) Shapiro-Wilk (SW stat $=0.974$, $p$-value $<0.010$ ), and (3) Kolmogorov-Smirnov (KS stat $=0.106, p$-value $<0.010)$. Thus, because the $p$-values are less than the significance level of 0.05 , the decision is to reject the null hypothesis, which indicates that the data do not follow a normal distribution.

Since the data might not follow a normal distribution, the individual distribution identification tool on the quality tools of Minitab ${ }^{\circledR}$ version 18.1 was used. Figure 8 summarizes the goodness of fit test parameters as directly lifted from the software results. AD is the Anderson-Darling goodness-of-fit statistic, which measures the deviation between the fitted line of the assumed distribution and the data points. $p$ is the $p$-value that is used to assess the fit of the distribution while LRT $p$ is the $p$-value for the likelihood-ratio test, which is used to see if adding another parameter improves the fit of the distribution over the one without it. Based on this figure, the best and most valid distribution which fits the 100 data sets from Bambusa blumeana is the Smallest Extreme Value distribution since it yielded a $p$-value $=0.073>0.05$. Note that the distribution, which requires a transformation, was not selected. The fitted distribution was further examined by visualizing the fit of data to the distribution as shown in Figure 9. Based on this figure, it can be inferred that most of the points fall close to the fitted distribution line, which indicates that the distribution is a good fit for the data. Indeed, Smallest Extreme Value is appropriate since this distribution is usually suitable for product failures related to load and strength [33]. Furthermore, while 
employing this distribution, you are usually primarily concerned with the extreme values that can lead to failure, rather than the distribution of variables that describe most of the population [33].

\section{Goodness of Fit Test}

\begin{tabular}{lrrr} 
Distribution & AD & P & LRT P \\
\hline Normal & 1.757 & $<0.005$ & \\
Box-Cox Transformation & 0.951 & 0.016 & \\
Lognormal & 3.867 & $<0.005$ & \\
3-Parameter Lognormal & 1.782 & $*$ & 0.000 \\
Exponential & 23.727 & $<0.003$ & \\
2-Parameter Exponential & 13.705 & $<0.010$ & 0.000 \\
Weibull & 1.602 & $<0.010$ & \\
3-Parameter Weibull & 0.692 & 0.030 & 0.011 \\
Smallest Extreme Value & 0.688 & 0.073 & \\
Largest Extreme Value & 3.565 & $<0.010$ & \\
Gamma & 3.056 & $<0.005$ & \\
3-Parameter Gamma & 1.966 & $*$ & 0.000 \\
Logistic & 1.609 & $<0.005$ & \\
Loglogistic & 2.977 & $<0.005$ & \\
3-Parameter Loglogistic & 1.614 & $*$ & 0.000 \\
Johnson Transformation & 0.203 & 0.874 &
\end{tabular}

Figure 8. The goodness of fit test parameters to identify individual distribution where AD is the Anderson-Darling goodness-of-fit statistic, $p$ is the $p$-value, and LRT $p$ is the $p$-value for the likelihoodratio test.

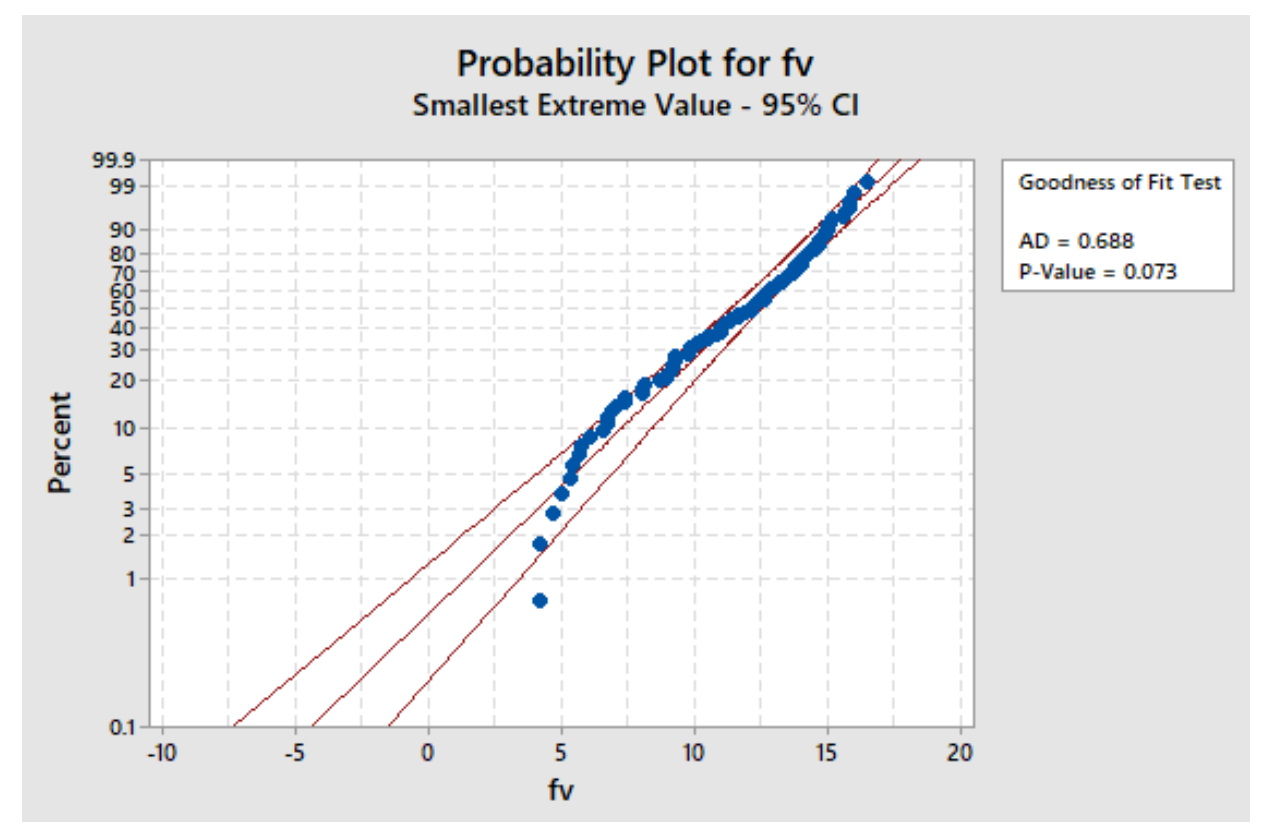

Figure 9. Probability plot for shear strength parallel to fiber $\left(f_{v}\right)$ considering the Smallest Extreme Value distribution with a $95 \%$ confidence interval. 


\section{Conclusions}

A total of five (5) bamboo species were selected in this study to determine the shear strength parallel to fiber using the (ISO 22157-1) shear test method. The average shear strength obtained for each bamboo species are as follows: Gigantochloa apus $\left(f_{v}=10.77 \mathrm{MPa}, \mathrm{COV}=0.264, n=30\right)$; Bambusa philippinensis $\left(f_{v}=9.68 \mathrm{MPa}\right.$, $C O V=0.160, n=30)$; Bambusa vulgaris $\left(f_{v}=9.26 \mathrm{MPa}, C O V=0.178, n=30\right)$; Dendrocalamus asper $\left(f_{v}=10.31 \mathrm{MPa}, \mathrm{COV}=0.192, n=30\right)$; Bambusa blumeana from Tarlac, Philippines $\left(f_{v}=11.44 \mathrm{MPa}, \mathrm{COV}=0.278, n=100\right)$. Results from one-way ANOVA suggest that there is a statistically significant difference between the obtained shear strength values for all species. Furthermore, it was validated that the shear test parallel to fiber is relatively insensitive to the presence of a node using the $t$-test method. Using linear regression analysis, a general model is established to estimate the shear strength value of bamboo using physical properties which can easily be obtained on-site. The linear model $f_{v}=0.0124 \rho+2.3903$ is proposed where shear strength $\left(f_{v}\right)$ is in $\mathrm{MPa}$, and the basic density $(\rho)$ is in $\mathrm{kg} / \mathrm{m}^{3}$. The ratio of shear strength $\left(f_{v}\right)$ and basic density $(\rho)$ equal to 0.016 is likewise suggested. This capability to estimate the mechanical properties of bamboo is particularly useful in contexts of nurseries and in forests, where there is limited access to testing facilities. Results also showed that the shear strength of bamboo is comparable to some timber species in the Philippines, thereby strengthening bamboo's position as an alternative material to wood.

The characteristic strength is also determined for each bamboo species using (ISO 121221 ) as a future design reference, especially in local practice. The characteristic shear strength obtained for each bamboo species are as follows: Gigantochloa apus $\left(f_{v, c}=5.11 \mathrm{MPa}\right) ;$ Bambusa philippinensis $\left(f_{v, c}=7.26 \mathrm{MPa}\right)$; Bambusa vulgaris $\left(f_{v, c}=6.46 \mathrm{MPa}\right)$; Dendrocalamus asper $\left(f_{v, c}=6.98 \mathrm{MPa}\right) ;$ Bambusa blumeana $\left(f_{v, c}=5.15 \mathrm{MPa}\right) ;$

When considering joint connection design in bamboo, the next aspect after characterizing the shear strength is to determine the effect of the different types of joint fasteners. Hence, it is recommended to test the effect of joint fasteners, such as bolts, wedges, pins, etc. in terms of shear. Moreover, since this study concentrated on only one aspect of the mechanical property of bamboo, it is hereby suggested that other mechanical properties such as bending, tensile, and compressive strength are studied as well. These four properties are crucial not only in the overall design of bamboo structures but also in future applications such as utilizing bamboo as a composite material. Another proposal is to test the effect of the position of the specimen on the bamboo culm on the shear strength of bamboo. Finally, it is recommended to test other economically important bamboo species in the Philippines.

Author Contributions: Conceptualization, L.F.L. and L.E.O.G.; methodology, L.F.L. and L.E.O.G.; validation, L.F.L. and L.E.O.G.; software, B.E.B.; formal analysis, B.E.B.; resources, L.F.L.; writingoriginal draft preparation, B.E.B.; writing-review and editing, L.F.L. and L.E.O.G.; supervision, L.F.L.; project administration, L.F.L. All authors have read and agreed to the published version of the manuscript.

Funding: This research received no external funding.

Institutional Review Board Statement: Not applicable.

Informed Consent Statement: Not applicable.

Data Availability Statement: The data presented in the study are available on request from the corresponding author.

Conflicts of Interest: The authors declare no conflict of interest. 


\section{References}

1. Salzer, C.; Wallbaum, H.; Lopez, L.F.; Kouyoumji, J.L. Sustainability of social housing in Asia: A holistic multi-perspective development process for bamboo-based construction in the Philippines. Sustainability 2016, 8, 151. [CrossRef]

2. International Bamboo and Rattan Organisation (INBAR). Nature Based Solutions at the United Nations General Assembly and Climate Action Summit. 2019. Available online: https:/ / www.inbar.int/inbar-and-nature-based-solutions-at-the-united-nationsgeneral-assembly-and-climate-action-summit/ (accessed on 6 January 2021).

3. International Bamboo and Rattan Organisation (INBAR). The Man from Ibarra who Discovered China's Famous 'Green Gold'. 2020. Available online: https://www.inbar.int/the-man-from-ibarra-who-discovered-chinas-famous-green-gold/ (accessed on 7 January 2021).

4. He, M.-X.; Wang, J.-L.; Qin, H.; Shui, Z.-X.; Zhu, Q.-L.; Wu, B.; Tan, F.-R.; Pan, K.; Hu, Q.-C.; Dai, L.; et al. Bamboo: A new source of carbohydrate for biorefinery. Carbohydr. Polym. 2014, 111, 645-654. [CrossRef] [PubMed]

5. Chen, X.; Zhang, X.; Zhang, Y.; Booth, T.; He, X. Changes of carbon stocks in bamboo stands in China during 100 years. For. Ecol. Manag. 2009, 258, 1489-1496. [CrossRef]

6. Chaowana, P. Bamboo: An Alternative Raw Material for Wood and Wood-Based Composites. J. Mater. Sci. Res. 2013. [CrossRef]

7. Akwada, D.R.; Akinlabi, E.T. Bamboo an alternative wood to reducing tropical deforestation in Ghana. In Proceedings of the DII-2018 Conference on Infrastructure Development and Investment Strategies for Africa, Livingstone, Zambia, 1-13 July 2018.

8. Nurdiah, E.A. The Potential of Bamboo as Building Material in Organic Shaped Buildings. Procedia Soc. Behav. Sci. 2016, 216, 30-38. [CrossRef]

9. Escamilla, E.Z.; Habert, G.; Daza, J.F.C.; Archilla, H.F.; Fernández, J.S.E.; Trujillo, D. Industrial or traditional bamboo construction? Comparative life cycle assessment (LCA) of bamboo-based buildings. Sustainability 2018, 10, 3096. [CrossRef]

10. Chen, M.; Weng, Y.; Semple, K.; Zhang, S.; Hu, Y.; Jiang, X.; Ma, J.; Fei, B.; Dai, C. Sustainability and innovation of bamboo winding composite pipe products. Renew. Sustain. Energy Rev. 2021, 144, 110976. [CrossRef]

11. Sun, X.; He, M.; Li, Z. Novel engineered wood and bamboo composites for structural applications: State-of-art of manufacturing technology and mechanical performance evaluation. Constr. Build. Mater. 2020, 249, 118751. [CrossRef]

12. Escamilla, E.Z.; Habert, G.; Wohlmuth, E. When $\mathrm{CO}_{2}$ counts: Sustainability assessment of industrialized bamboo as an alternative for social housing programs in the Philippines. Build. Environ. 2016, 103, 44-53. [CrossRef]

13. Aggangan, R. The Philippine Bamboo Industry: Issues, Potentials, Strategies and Action Programs. In Proceedings of the 10th World Bamboo Congress, Damyang, Korea, 17-22 September 2015.

14. Department of Science and Technology. Demand in Construction Industry—Bamboo Information Network. 2020. In the Local Setting, One of the Primary Demands for Bamboo for Housing Purposes Arises from the Need for New House Construction and for Repair and Replacement of Existing Houses. Available online: http://www.pcaarrd.dost.gov.ph/home/momentum/bamboo/ index.php?option=com_content\&view=article\&id=243:demand-in-construction-industry\&catid=127:articles\&Itemid=10 (accessed on 1 February 2020).

15. Department of Trade and Industry—Board of Investments (DTI-BOI). Housing Roadmap—Securing the Future of Philippine Industries. 2020. Available online: http://industry.gov.ph/industry/housing/ (accessed on 8 January 2021).

16. Hong, C.; Li, H.; Xiong, Z.; Lorenzo, R.; Corbi, I.; Corbi, O.; Wei, D.; Yuan, C.; Yang, D.; Zhang, H. Review of connections for engineered bamboo structures. J. Build. Eng. 2020, 30, 101324. [CrossRef]

17. Kamruzzaman, M.; Saha, S.K.; Bose, A.K.; Islam, M.N. Effects of age and height on physical and mechanical properties of bamboo. J. Trop. For. Sci. 2008, 20, 211-217.

18. Karimah, A.; Ridho, M.R.; Munawar, S.S.; Adi, D.S.; Ismadi; Damayanti, R.; Subiyanto, B.; Fatriasari, W.; Fudholi, A. A review on natural fibers for development of eco-friendly bio-composite: Characteristics, and utilizations. J. Mater. Res. Technol. 2021, 13, 2442-2458. [CrossRef]

19. Harries, K.A.; Sharma, B.; Richard, M. Structural Use of Full Culm Bamboo: The Path to Standardization. Int. J. Archit. Eng. Constr. 2012, 1, 66-75. [CrossRef]

20. Trujillo, L.; Lopez, D. Bamboo Material Characterisation. In Nonconventional and Vernacular Construction Materials Characterisation, Properties and Applications, 1st ed.; Harries, K.A., Sharma, B., Eds.; Woodhead Publishing: Cambridge, UK, 2016 ; pp. 365-392. [CrossRef]

21. Gauss, C.; Savastano, H.; Harries, K.A. Use of ISO 22157 mechanical test methods and the characterisation of Brazilian P. edulis bamboo. Constr. Build. Mater. 2019, 228, 116728. [CrossRef]

22. Janssen, J. International standards for bamboo as a structural material. Struct. Eng. Int. J. Int. Assoc. Bridg. Struct. Eng. 2005, 15, 48. [CrossRef]

23. Gatóo, A.; Sharma, B.; Bock, M.; Mulligan, H.; Ramage, M.H. Sustainable structures: Bamboo standards and building codes. Proc. Inst. Civ. Eng. Eng. Sustain. 2014, 167, 189-196. [CrossRef]

24. Cantos, G.L.; Lopez, L.F.; de Jesus, R.M.; Salzer, C.; Garciano, L.E.O. Investigation of an alternative testing protocol to determine the shear strength of bamboo parallel to the grain. Maderas Cienc. Tecnol. 2019, 21, 559-564. [CrossRef]

25. Mitch, D.R. Splitting Capacity Characterization of Bamboo Culms. Doctoral Dissertation, University of Pittsburgh, Pittsburgh, PA, USA, 2019.

26. Takeuchi, C.P.; Estrada, M.; Linero, D.L. Experimental and numerical modeling of shear behavior of laminated Guadua bamboo for different fiber directions. Constr. Build. Mater. 2018, 177, 23-32. [CrossRef] 
27. Deng, J.; Chen, F.; Wang, G.; Zhang, W. Variation of Parallel-to-Grain Compression and Shearing Properties in Moso Bamboo Culm (Phyllostachys pubescens). BioResources 2015, 11, 1784-1795. [CrossRef]

28. Janssen, J. Bamboo in Building Structues. Ph.D. Thesis, Technical University of Eindhoven, Eindhoven, The Netherlands, 1981.

29. International Organization for Standardization (ISO). ISO 22157-1:2017-Bamboo-Determination of Physical and Mechanical Properties; ISO: Geneva, Switzerland, 2017.

30. International Organization for Standardization (ISO). ISO 12122-1:2014-Timber Structures—Determination of Characteristic ValuesPart 1: Basic Requirements; ISO: Geneva, Switzerland, 2014.

31. Bello, E.; Mosteiro, A. Manual on the Properties and Uses of Lesser-Used Species of Philippine Timbers. 1997. Available online: http:/ / www.itto.int/files/user/pdf/publications/PD47\%2088/pd47-88-1\%20rev\%203\%20(I)\%20e.pdf (accessed on 12 July 2021).

32. Valencia, F.V. Mechanical Tests of Some of Commercial Philippine Timbers. Philipp. J. Sci. 1921, 18, 485-535.

33. Minitab 18 Statistical Software; Minitab, Inc.: State College, PA, USA, 2017. Available online: www.minitab.com (accessed on 12 July 2021). 